\title{
HISTORY OF PLASMA THERAPY: A CURRENTLY USED TREATMENT OPTION FOR COVID-19
}

\section{PLAZMA TEDAVISININ TARIHI: COVID-19 ENFEKSIYONU IÇIN GÜNÜMÜZDE KULLANILMAKTA OLAN BIR TEDAVI SEÇENEĞi}

\author{
Esra BILIR (D), Emine Elif VATANOĞLU LUTZ² (D), Ayşe Arzu AKALIN³ \\ ${ }^{1}$ American University of Sovereign Nations, School of Medicine, Sacaton, AZ, USA \\ ${ }^{2}$ Istanbul University, Istanbul Faculty of Medicine, Department of Medical History and Ethics, Istanbul, Turkey \\ ${ }^{3}$ Yeditepe University, Faculty of Medicine, Department of Family Medicine, Istanbul, Turkey
}

ORCID IDs of the authors: E.B. 0000-0003-4499-6543; E.E.V.L. 0000-0003-3156-4733; A.A.K. 0000-0001-6384-2035

Cite this article as: Bilir E, Vatanoglu Lutz EE, Akalin AA. History of plasma therapy: a currently used treatment option for COVID-19. J Ist Faculty Med 2021;84(3):411-4. doi: 10.26650/IUITFD.2020.0106

\section{ABSTRACT}

The current pandemic provides the most incredible opportunity to develop convalescent plasma therapy into an effective treatment modality for the coronavirus disease 2019 (COVID-19) caused by Severe Acute Respiratory Syndrome Coronavirus-2 (SARS-CoV-2) while a vaccine is still under development. The global reach of this pandemic, and the immediate need for effective treatments for patients with severe and critical COVID-19, is driving both basic and clinical research at an unprecedented rate. Convalescent plasma therapy is a treatment option that has been known since the 1900s and has been used in various disease treatments since then. Convalescent plasma therapy is one of the treatments currently being used in the treatment of patients with COVID-19. We see that this treatment method was likewise used in the Middle East respiratory syndrome coronavirus (MERS-CoV), the severe acute respiratory syndrome (SARS), and Ebola epidemics, which occurred worldwide in the recent past. This review aims to provide an overview of plasma therapy's history and the scientists behind this vital discovery. Secondarily, we report the recent global advances in convalescent plasma use in COVID-19 treatment.

Keywords: COVID-19, convalescent plasma therapy, history

\begin{abstract}
ÖZET
İçinde bulunduğumuz mevcut pandemide "Severe Acute Respiratory Syndrome Coronavirus-2" (SARS-CoV-2) virüsünün neden olduğu yeni koronavirüs hastalığı (COVID-19) için aşı geliştirme çalışmaları devam ederken, konvalesan plazma tedavisi de etkili bir tedavi yöntemi olarak bir fırsat sunmaktadır. Bu pandemide, şiddetli ve kritik COVID-19 hastaları için etkili acil tedavilere ihtiyaç duyulmakta, hem temel hem de klinik araştırmalar benzeri görülmemiş bir hızda devam etmekte ve bir çok çalışma konvalesan plazma tedavisine yönlendirmektedir. Konvalesan plazma tedavisi, 1900'lerden beri bilinen ve o zamandan beri çeşitli hastalıklarda kullanılan bir tedavi seçeneğidir. Konvalesan plazma tedavisi halihazırda COVID-19 tanılı hastaların tedavisinde kullanılan tedavi seçeneklerinden birisidir. Yakın geçmişte dünyayı etkisi altına alan the Middle East respiratory syndrome coronavirus (MERS-CoV), the severe acute respiratory syndrome (SARS) ve Ebola salgınlarında da bu tedavi yönteminin uygulandığını görmekteyiz. Bu derlemede konvalesan plazma tedavisinin tarihçesine ve bu hayati buluşun arkasındaki bilim insanlarına genel bir bakış atmayı amaçlıyoruz. İkincil olarak, COVID-19'un tedavisinde dünyadaki plazma kullanımındaki küresel gelişmeleri sunmak hedeflendi.
\end{abstract}

Anahtar Kelimeler: COVID-19, konvalesent plazma tedavisi, tarihçe

Corresponding author/iletişim kurulacak yazar: drvatanoglu@yahoo.com

Submitted/Başvuru: 16.09.2020 • Accepted/Kabul: 04.11.2020 • Published Online/Online Yayın: 26.05.2021 
Coronavirus disease 2019 (COVID-19) caused by severe acute respiratory syndrome coronavirus 2 (SARS-CoV-2) was declared a pandemic on March 11, 2020 by the World Health Organization (WHO) (1). Since then scientists and clinicians have been extensively working to find a cure for COVID-19 and also produce an effective vaccine against SARS-CoV-2. High-quality evidence showing the effectiveness of treatments for COVID-19 is scarce, but recent studies are now registered in testing a range of therapies, including immunosuppressants and remdesivir. One therapy being tested is convalescent plasma, also known as an immune plasma or hyperimmune plasma, is a type of passive antibody therapy, in which blood plasma is isolated from people who have recovered from the disease of interest and is administered to those with the disease to suppress viremia and improve clinical symptoms (2). In this review, we aim to briefly present the history of convalescent plasma therapy. As the secondary goal of this review, we report the recent global advances in convalescent plasma use in COVID-19 treatment.

The acquisition of immunity to a disease that a patient has already encountered has been documented for many centuries. Some of the earliest work in the field that has now become known as immunology was performed in the period around 1714-1717 (3). Lady Mary Wortley Montagu pioneered a smallpox inoculation, a course of action unparalleled in medical progress up to that point. Variolation used live smallpox virus in the liquid taken from a smallpox blister in a mild case of the disease and was carried in a nutshell. In 1798, the first smallpox vaccination was more notably demonstrated by Edward Jenner. This was performed by inoculating a boy with the fluid from a cowpox pustule giving him immunity to the very similar but much more severe disease smallpox (3).

Emil von Behring, lived between 1854 and 1917, and studied medicine at the Kaiser-Wilhelm-Akademie in Berlin, an academy for military doctors. He had ascertained that the serum of tetanus-immune white rats contained a substance that neutralized anthrax bacilli in 1887 and saw this as the cause of "resistance" (4). In early 1889 , he worked in Berlin with Shibasaburo Kitasato on the isolation and definition of this agent. One of their goals was still the discovery of suitable systemic disinfecting agents, especially against anthrax, for which iodine, gold, and zinc compounds were tested. On December 4, 1890, Behring and Kitasato jointly published their first paper on blood-serum therapy, followed on 11 December by another report, signed by Behring alone, which discussed the blood-serum therapy not only in the treatment of tetanus but also of diphtheria (4). In that article, he stressed four main points:

1- The blood of tetanus-immune rabbits possesses tetanus toxin-destroying properties.
2- These properties are also present in extravascular blood and the cell-free serum obtained from the latter.

3- These properties are so lasting that they remain effective when injected into other animals, thus making it possible to achieve excellent therapeutic effects with blood or serum transfusions.

4- Tetanus toxin-destroying properties are not present in the blood of animals, not immune to tetanus (4).

Behring immediately recognized that evidently, a new principle of defense by the organism against infection had been discovered. Behring won the first Nobel Prize in Physiology or Medicine in 1901 to develop serum therapies against diphtheria (3).

In the same time interval in 1900, we also see Paul Ehrlich, who is regarded as one of the pioneers of modern immunology, proposed the side-chain theory, where he hypothesized that side-chain receptors on cells bind to a given pathogen. He was the first to propose a model for an antibody molecule in which the antibody was branched and consisted of multiple sites for binding to foreign material, known as antigen, and for the activation of the complement pathway. This model agreed with the 'lock and key' hypothesis for enzymes proposed by Emil Fischer and still in general terms holds true today (5).

In 1944, Swedish physician Jan G. Waldenström described a case of macroglobulinemia with symptoms of increased blood viscosity. In 1955, Jan G. Walderstrom performed an effective plasmapheresis procedure on a patient with macroglobulinemia and noted an effective reduction of macroglobulin in the blood. Astrid Fagraeus, in 1948 described that plasma B cells were specifically involved in antibody generation. By 1957 Frank Burnet and David Talmage had developed the clonal selection theory. This stated that a lymphocyte makes a single specific antibody molecule that is determined before it encounters an antigen, which was in contrast to the instructive theory developed by Linus Pauling in 1940, where the antigen acted as a template for the antibody (4).

By 1959 Gerald Edelman and Rodney Porter had independently published the molecular structure of antibodies, for which they were later jointly awarded the Nobel Prize in 1972 (6). The first atomic-resolution structure of an antibody fragment was published in 1973. That was quickly followed by the invention of monoclonal antibodies in 1975 by Georges Köhler and César Milstein, signaling the start of the modern era of antibody research and discovery (5). Today the term plasma therapy includes different techniques (filtration or adsorption on plasma), which remove not all, but only specific elements contained in the plasma and altogether allow treatment of a large number of diseases (7). 
Our recent history regarding the use of convalescent plasma therapy against viral infections therapy includes the severe acute respiratory syndrome (SARS) epidemic, the Middle East respiratory syndrome coronavirus (MERS-CoV) epidemic, and the Ebola epidemic (8-10). Human-to-human transmission of SARS and MERS-CoV is through respiratory droplets, but the Ebola virus was transmitted via body fluids, including urine, saliva, sweat, feces, breast milk, and semen (11). In late 2002, the SARS epidemic emerged in China. In nine months, WHO shared the data on the SARS epidemic as over eight thousand people infected, where almost 800 deaths had occurred, leading to a case fatality ratio of $9.6 \%$ (12). The results of a study included 80 patients with SARS in Hong Kong supported the use of convalescent plasma therapy in the early phase of SARS (8). In late 2012, the MERS-CoV epidemic started in Saudi Arabia (9). Since the case fatality rate was too high, reaching almost $50 \%$, many experimental therapies evaluated against MERS-CoV infection, where one was convalescent plasma therapy supported by WHO (13). However, a feasibility study, conducted to investigate the use of convalescent plasma therapy against MERS-CoV, did not show the high-titer convalescent plasma for passive immunotherapy of MERS-CoV infection (14). As part of the conclusions, the authors emphasized the need for well-designed clinical trials (14). Thus far, we had seen several Ebola virus outbreaks, where the first one was believed to be in 1976 in Sudan (15). The overall case fatality rate has reached to $40 \%$ (15). A study evaluating the use of convalescent plasma therapy against Ebola infection concluded that the therapy did not result in significant improvement in survival where it included a total of 84 patients with confirmed previous Ebola infection (10). These experiences with the use of convalescent plasma therapy showed that there is a need for improvement in this option to work better in the clinic.

According to WHO reports, COVID-19 had caused more than 900,000 deaths and infected more than 28 million people in the world at the time of writing this review (16). While the research being conducted to find an effective medical regimen to treat patients with COVID-19, convalescent plasma therapy remains as one of the options investigated against COVID-19. Many countries, including Turkey encouraged the recovered patients from COVID-19 to donate blood that will be used for convalescent plasma therapy for hospitalized patients with COVID-19. Currently, the optimal antibody titer that should be used in convalescent plasma, is not well known. Thus, we need clinical studies to establish the titer values to make convalescent plasma therapy better. The United States of America's (USA) authority, known as the Food and Drug Administration (FDA) did not give license to convalescent plasma therapy for its use in treating patients with COVID-19. However, the FDA released a letter in response to Robert P. Kadlec's, MD, MTM\&H,
MS request on the use of convalescent plasma therapy for COVID-19 on August 23, 2020 and granted its use as Emergency Use Authorization (EUA) (17). Ten days later, on September 2, 2020, the FDA resealed new guidance called "Recommendations for Investigational COVID-19 Convalescent Plasma" (18). Since the clinical trials are the gold standard research tool for investigating the effectiveness of a treatment, we aimed to evaluate the ongoing clinical trials being conducted in a search at www. clinicaltrials.gov where we used "Covid19" as Condition or disease and "Convalescent plasma" as Other terms on September 12, 2020. This search yielded 148 clinical trials in total, where the majority (37.8\%) came from the USA. Ten of these clinical trials were reported to be completed, whereas only one was withdrawn.

Despite its 100-years-plus history, never before has the use of convalescent plasma been so thoroughly tested for use as a viable therapeutic. Whatever the outcome of the many clinical trials being conducted, we will undoubtedly learn a lot about the most efficient ways to collect, process, and safely use convalescent plasma. The medical world is so far hopeful for a positive outcome for convalescent plasma use in COVID-19. Fortunately, our improved understanding of convalescent plasma will also be valuable for pandemics of the future.

Peer Review: Externally peer-reviewed.

Author Contributions: Conception/design of study- E.B., E.E.V.L.; Data acquisition- E.B., E.E.V.L.; Data analysis/interpretation- E.B., E.E.V.L., A.A.A.; Drafting manuscript- E.B., E.E.V.L., A.A.A.; Critical revision of manuscript- E.B., E.E.V.L., A.A.A.; Final approval and accountability- E.B., E.E.V.L., A.A.A.

Conflict of Interest: Authors declared no conflict of interest.

Financial Disclosure: Authors declared no financial support.

Hakem Değerlendirmesi: Dış bağımsız.

Yazar Katkıları: Çalışma konsepti/tasarım- E.B., E.E.V.L.; Veri toplama- E.B., E.E.V.L.; Veri analizi/yorumlama- E.B., E.E.V.L., A.A.A.; Yazı taslağı- E.B., E.E.V.L., A.A.A.; İçeriğin eleştirel incelemesi- E.B., E.E.V.L., A.A.A.; Son onay ve sorumluluk- E.B., E.E.V.L., A.A.A.

Çıkar Çatışması: Yazarlar çıkar çatışması beyan etmemişlerdir.

Finansal Destek: Yazarlar finansal destek beyan etmemişlerdir.

\section{REFERENCES}

1. World Health Organization. WHO Director-General's opening remarks at the media briefing on COVID-19 - 11 March 2020. (cited 2020 August 27), Available from: URL: https://www.who.int/dg/speeches/detail/who-directorgeneral-s-opening-remarks-at-the-media-briefing-oncovid-19---11-march-2020. 
2. Li L, Zhang W, Hu Y, Tong X, Zheng S, Yang J, et al. Effect of Convalescent Plasma Therapy on Time to Clinical Improvement in Patients With Severe and Lifethreatening COVID-19: A Randomized Clinical Trial. JAMA. 2020;324(5):460-70. doi: 10.1001/jama.2020.10044. Erratum in: JAMA 2020;324(5):519. [CrossRef]

3. Kaufmann SHE. Emil von Behring: translational medicine at the dawn of immunology. Nat Rev Immunol 2017;17(6):3413. [CrossRef]

4. Sanz ML. Legends of Allergy/lmmunology: Albert K. Oehling. Allergy 2019;74(2):382-4. [CrossRef]

5. Gmelig-Meyling FH, Meyaard L, Mebius RE. 50 years of Dutch immunology--founders, institutions, highlights. Immunol Lett. 2014;162(2 Pt B):85-94. doi: 10.1016/j. imlet.2014.10.014. Epub 2014 Oct 16. Erratum in: Immunol Lett. 2015 May;165(1):62. [CrossRef]

6. The Nobel Prize in Physiology or Medicine 1972. (cited 2020 August 27), Available from: URL: https://www.nobelprize. org/prizes/medicine/1972/summary/.

7. Bloch EM, Shoham S, Casadevall A, Sachais BS, Shaz B, Winters $J L$, et al. Deployment of convalescent plasma for the prevention and treatment of COVID-19. J Clin Invest 2020;130(6):2757-65. [CrossRef]

8. Cheng Y, Wong R, Soo YO, Wong WS, Lee CK, Ng MH, et al. Use of convalescent plasma therapy in SARS patients in Hong Kong. Eur J Clin Microbiol Infect Dis 2005;24(1):44-6. [CrossRef]

9. Mclntosh, K. Middle East respiratory syndrome coronavirus: Treatment and prevention. In: UpToDate, Post TW (Ed), UpToDate, Waltham, MA. (cited 2020 September 12)

10. van Griensven J, Edwards $T$, de Lamballerie $X$, Semple MG, Gallian P, Baize S, et al. Evaluation of Convalescent Plasma for Ebola Virus Disease in Guinea. N Engl J Med 2016;374(1):33-42. [CrossRef]
11. Centers for Disease Control and Prevention. Review of human-to-human transmission of Ebola virus. (cited 2020 September 12), Available from: URL: http://www.cdc.gov/ vhf/ebola/transmission/human-transmission.html.

12. World Health Organization. Summary of probable SARS cases with onset of illness from 1 November 2002 to 31 July 2003 (based on data as of the 31 December 2003). (cited 2020 September 12), Available from: URL: http://www.who. int/csr/sars/country/table2004_04_21/en/index.html.

13. World Health Organization. WHO-ISARIC joint MERS-CoV Outbreak Readiness Workshop: Clinical management and potential use of convalescent plasma. (cited 2020 September 12), Available from: URL: http://www.who. int/csr/disease/coronavirus_infections/MERS_outbreak_ readiness_workshop.pdf.

14. Arabi YM, Hajeer AH, Luke T, Raviprakash $\mathrm{K}$, Balkhy $H$, Johani S, et al. Feasibility of Using Convalescent Plasma Immunotherapy for MERS-CoV Infection, Saudi Arabia. Emerg Infect Dis 2016;22(9):1554-61. [CrossRef]

15. Bray M, Chertow DS. Epidemiology and pathogenesis of Ebola virus disease. In: UpToDate, Post TW (Ed), UpToDate, Waltham, MA. (cited 2020 September 12) [CrossRef]

16. WHO Coronavirus Disease (COVID-19) Dashboard. (cited 2020 September 12), Available from: URL: https://covid19. who.int.

17. US Food and Drug Administration. Emergency use authorization for convalescent plasma. (cited 2020 September 12), Available from: URL: https://www.fda.gov/ media/141477/download.

18. US Food and Drug Administration. Recommendations for Investigational COVID-19 Convalescent Plasma. (cited 2020 September 12), Available from: URL: https://www.fda.gov/ vaccines-blood-biologics/investigational-new-drug-ind-ordevice-exemption-ide-process-cber/recommendationsinvestigational-covid-19-convalescent-plasma. 